論文

$$
\text { オーステナイト系ステンレス鋼火 SUS304J1HTB のクリープ劣化 }
$$

\author{
久布白 圭司* 塩田 佳紀* 野村 恭兵*
}

\title{
Creep Degradation for Austenitic Stainless steel in KA-SUS304J1HTB
}

by

Keiji Kubushiro *, Yoshiki ShiodA* and Kyohei Nomura *

The microstructures of the KA-SUS304J1HTB (ASME code: 2328) were investigated in order to clarify the reason for the onset of accelerating creep. Creep tests were conducted at $873 \mathrm{~K}$ for a stress range from $240 \mathrm{MPa}$ to 300 $\mathrm{MPa}$. Creep interrupted tests were also conducted at $873 \mathrm{~K}$ for a stress of $240 \mathrm{MPa}$. Creep deformation of the KA-SUS304J1HTB was divided into the following three regions: transient creep, minimum creep and accelerating creep. The creep life of the KA-SUS304J1HTB consisted mostly of accelerating creep, regardless of the stress conditions. The creep cracks initiated along the grain boundary due to accelerating creep and the number and length of the creep cracks increased in accordance with the creep time. In addition, the results of microstructure observations conducted using the electron channeling contrast image (ECCI) method indicated that dynamic recovery and sub-grain formation around the grain boundaries occurred during the accelerating creep region. On the other hand, dynamic recovery in the grain did not occur under this condition. Increments in the grain orientation spread (GOS) produced by creep were almost the same as those produced by high temperature tensile deformation, although the deformation mode was different. The values calculated using the GOS increased with the strain increasing linearly. However, the large misorientation area calculated by kernel average misorientation (KAM) was only localized near the grain boundaries under the creep condition.

Key words:

Creep damage, KA-SUS304J1HTB, SUPER304H, Creep crack, ECCI method, EBSD

\section{1 緒言}

火 SUS304J1HTB (ASME code 2328) は，高温強度に優 れたオーステナイト系ステンレス鋼 ${ }^{1)}$ であり, ボイラチュ ーブとして $600^{\circ} \mathrm{C}$ 級 USC プラントに多数適用されている. この材料の特徴は微細 $\mathrm{Cu}$ 相の析出強化により, 従来の SUS316HTB, SUS304HTB などのオーステナイトステンレ ス鋼に比べ高い許容応力を示すことである.これまで, 従来のオーステナイト系ステンレス鋼のクリープ損傷過

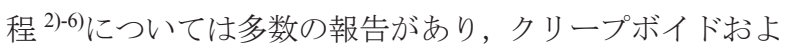
びき裂の発生による損傷, 粒界に析出したシグマ相と母 相の界面からクリープ破壊が生じることなどが報告され ている.

ところで，火力発電ボイラでは長時間使用後に配管の 寿命評価などを行うことが多いため，材料のクリープ破 壊入カニズムを解明することは非常に重要と考えられる。 しかしながら, 火 SUS304J1HTBについては, 組織変化に 関する研究 ${ }^{7)-9)}$, 材料強度評価 ${ }^{10)}$, 高温腐食など ${ }^{11)-14)}$ に関 する研究は報告されているものの，そのクリープ劣化メ カニズムについて言及した研究はほとんどない，そこで 本研究では, 火 SUS304J1HTB のクリープ特性を明らかに するとともに，その劣化メカニズムを明らかにすること
を目的とした。

\section{2 実験方法}

供試材は，火 SUS304J1HTB のチューブ材である.クリ ープ試験片は, 平行部径 $\phi 6 \mathrm{~mm}$, 評点間距離 $30 \mathrm{~mm}$ に加工 した. 試験温度は $650^{\circ} \mathrm{C}$, 応力は $300 \sim 240 \mathrm{MPa}$ の 4 条件 である．粒界き裂の発生が今回の試験範囲で最も顕著で あった応力 $240 \mathrm{MPa}$ の試験については, クリープ劣化要因 を明らかにするためクリープ中断試験も行った. クリー プき裂の観察は，光学顕微鏡を用いた。観察用のサンプ ルは次のように準備した。 まず, 破断および中断した試 験片を引張応力軸および供試チューブ材径方向平行断面 となるよう切出し, 表面をエメリー紙にて\#2000まで湿式 研磨した後，ダイヤモンド研磨およびアルミナ研磨にて 鏡面に仕上げた。その後, 塩化第二鉄溶液にてエッチン グした.クリープひずみ分布については, SEM/EBSD 法 により得られた方位差により推定した。

EBSD 測定には, 湿式研磨およびダイヤモンド研磨によ り表面を鏡面に仕上げた後, 酸化物研磨懸濁液 OP-S にて 环磨仕上げしたサンプルを用いた。 EBSD 測定装置には， TSL 社製 EBSD 検出器を用いた. EBSD 測定条件は, 加速 電圧 $20 \mathrm{kV}, \mathrm{WD}=15 \mathrm{~mm}$ とし, 測定ピッチ $1 \mu \mathrm{m}$, 測定範

$\dagger \quad$ 原稿受理 平成 28 年 7 月 12 日 Received July 21, 2016 C2017 The Society of Materials Science, Japan

* 正会員 (株) IHI 基盤技術研究所 $=235-8501$ 横浜市磯子区新中原町, Research Laboratory, IHI Corporation, Isogo-ku, Yokohama 235-8501 
囲 $200 \mu \mathrm{m} \times 400 \mu \mathrm{m}$ である. 各サンプルの測定視野はそれ ぞれ 3 視野とし, 切出した平行部断面に対し応力軸と垂 直方向を $\mathrm{t}$ 方向として $1 / 4 \mathrm{t}, 1 / 2 \mathrm{t}$ および $3 / 4 \mathrm{t}$ の位置にて EBSD測定を行った. EBSD解析に用いたソフトウェアは, TSL 社製 OIM ver.7 である. 粒内の平均方位差の指標とし て, $\Delta \operatorname{GOS}_{\mathrm{Ave}}$ (area)を用い, 粒内の方位差分布の評価には, KAM を用いた。 それぞれの值の算出方法は，「電子後方 散乱回折（EBSD）法による材料評価のための結晶方位差 測定標準」に従った ${ }^{15)}$. 中断材の析出物の観察には SEM 反射電子を用い, 含有元素の重さの違いにより析出物を 推定した。また SEM-ECCI(Electron Channeling Contrast Imaging)法により, サブグレイン組織の観察を実施した. ECCI 法とは, 電子チャネリングのコントラストにより, 材料中の欠陥, サブバウンダリーなどを観察する技術で ある．ECCI 法の観察条件は，加速電圧 $15 \mathrm{kV}, \mathrm{WD}=3 \mathrm{~mm}$ である。

\section{3 実験結果および考察}

\section{$3 \cdot 1$ クリープ試験結果}

クリープ前の初期組織を Fig.1 に示す. 平均結晶粒径は 約 $60 \mu \mathrm{m}$ であった. 未固溶の炭化物が管長手方向に沿って 多数観察された。ビッカース硬さは，167HVであった。

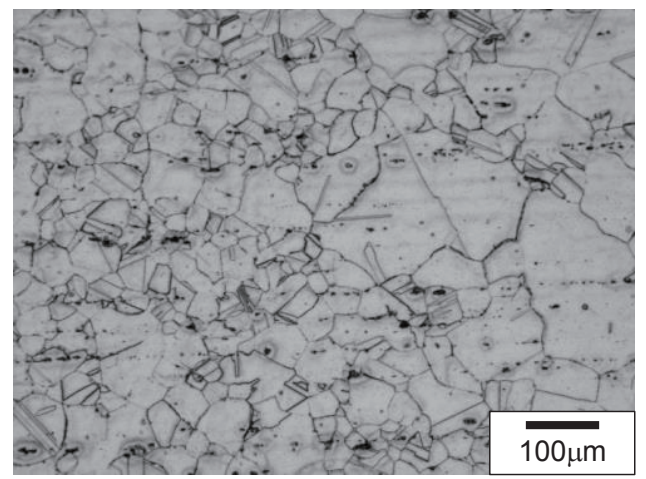

Fig. 1 Initial microstructure of KA-SUS304J1HTB

$650^{\circ} \mathrm{C}$ におけるクリープ速度一時間曲線およびクリー プ速度ークリープ寿命比曲線を Fig. 2 および 3 に示す. い ずれの応力においても，まず時間とともにクリープ速度 が減少する遷移クリープが生じ，最小クリープ速度を示 した後, 加速クリープを示した. 加速クリープの開始は, 寿命の約 0.1 から 0.3 程度で生じ, 寿命の大半が加速クリ ープであった．寿命に占める加速クリープの割合は，低 応力ほど小さかった。 また, 応力が小さいほど最小クリ ープ速度は小さかった。

次に加速クリープ域での組織変化を明らかにするため, $650^{\circ} \mathrm{C} ， 240 \mathrm{MPa}$ にてクリープ中断試験を実施した結果を

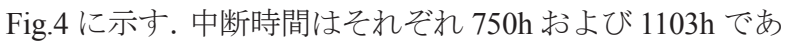
り，全寿命に対し 0.47 および 0.70 である. 以降，寿命比 を用いて記述する。これら中断材についてミクロ組織を 観察し，加速の原因について調査した。

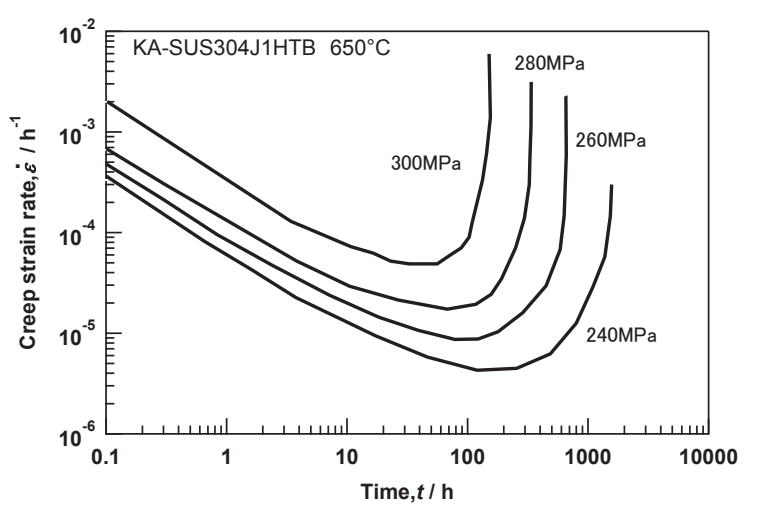

Fig. 2 Creep rate - time curves of KA-SUS304J1HTB at $650^{\circ} \mathrm{C}$ and the stress range from 300 to $240 \mathrm{MPa}$

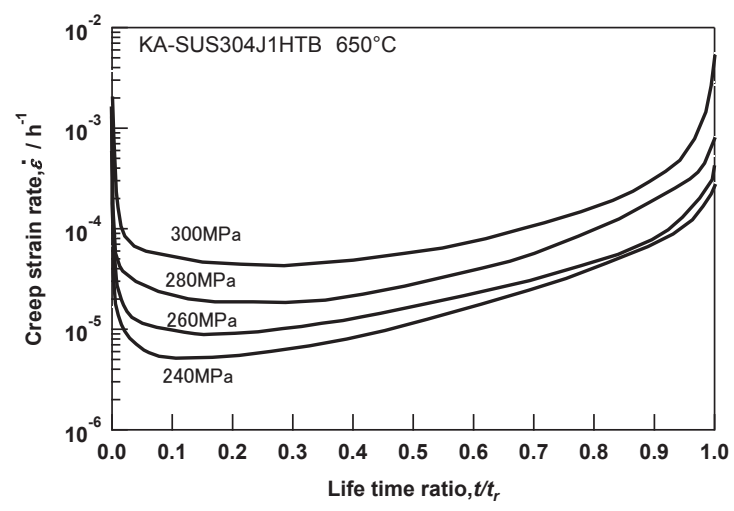

Fig. 3 Creep rate - life time ratio curves of KA-SUS304J1HTB at $650^{\circ} \mathrm{C}$ and the stress range from 300 to $240 \mathrm{MPa}$

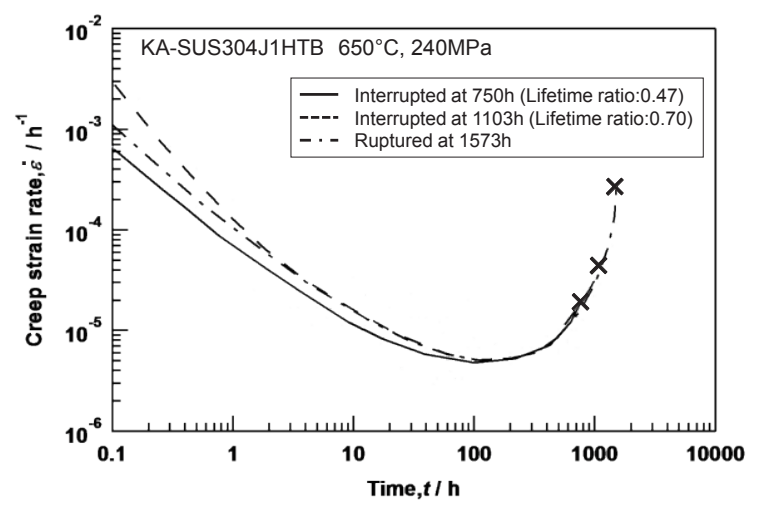

Fig.4 Creep rate - time curves of KA-SUS304J1HTB at $650^{\circ} \mathrm{C}$, $240 \mathrm{MPa}$

\section{$3 \cdot 2$ クリープ中断材のミクロ組織}

$650^{\circ} \mathrm{C} ， 240 \mathrm{MPa}$ におけるクリープ中断後および破断後 の光学顕微鏡組織を Fig.5 に示す. 光学顕微鏡で観察され る範囲において, 寿命比 0.47 の中断材では, 微細なクリ ープき裂が試験片外表面(a)および試験片内部(b)に発生し ていた．最大クリープき裂長さは約 $100 \mu \mathrm{m}$ であり, クリ ープき裂の数はわずかであった。

寿命比 0.70 の中断材では, 試験片外表面(c)および内部 (d)でのクリープき裂長さは増加し, その数も増加してい た。クリープ破断材では，外表面(e)および内部(f)ではク リープき裂の数が著しく増加していた. 寿命比約 0.5 から クリープき裂が発生し，その長さおよび数が増加するこ 
とは、これまでのオーステナイト系ステンレス鋼のクリ ープ損傷形態に関する報告と一致した ${ }^{16)-18)}$.
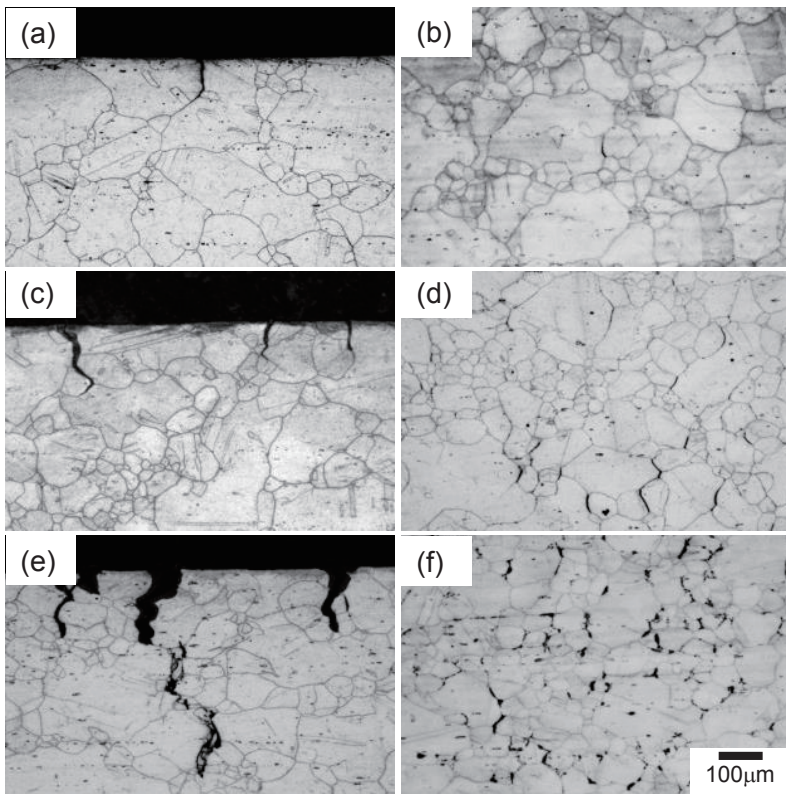

Fig.5 Crack development with increasing creep time in

KA-SUS304J1HTB at $650^{\circ} \mathrm{C}, 240 \mathrm{MPa}$, (a) Surface of lifetime ratio 0.47 specimen, (b) center of lifetime ratio 0.47 specimen, (c) Surface of lifetime ratio 0.70 specimen, (d) center of lifetime ratio 0.70 specimen, (e) Surface of the ruptured specimen at $10 \mathrm{~mm}$ away from rupture area , (f) center of the ruptured specimen at $10 \mathrm{~mm}$ away from rupture area.

\section{$3 \cdot 3$ クリープ中断時の方位差分布}

前項にて加速クリープ域では，クリープき裂が発生し， 増加していた。 そこで，加速クリープ域においてクリー プき裂が発生する要因を検討するため，SEM/EBSD 法の 結果より方位差マップを評価した。クリープ中断材の Kernel Average Misorientation (KAM)マップを Fig.6 に示す. 併せて，同一サンプルにおいて $650^{\circ} \mathrm{C} に て 5 \%$ の張中断 試験を実施したサンプルの KAM マップ 19)も示す，KAM マップは，第 5 近接データにより方位差を計算し，方位 差の大小により色分けを実施した。なお，Fig.6 に示す KAM マップの観察位置は，中断材では試験片長手断面の 肉厚中央を，破断材では破断部から $10 \mathrm{~mm}$ 以上離れた局 所絞りが発生していない試験片長手断面の肉厚中央部で ある。方位差は青色が最も小さく，緑，黄，赤の順で大 きい. なお， $5 \%$ 引張中断材 (d)で確認される黒い点は, 研 磨時のピットなどによる測定不良領域である。クリープ 負荷前(a)では測定視野のほとんどが青色を示し，方位差 はほとんどなかった。寿命比 0.47 , 中断歪み $5.1 \%$ にて中 断したサンプル(b)では，矢印に示す領域において，結晶 粒界近傍の一部で黄緑を示し，結晶粒界近傍で方位差が 大きかった．寿命比 0.70 , 中断歪み $5.9 \%$ にて中断したサ ンプルでは，ひずみの変化は(b)と比べわずか $0.8 \%$ にもか かわらず，結晶粒界近傍および粒界 3 重点において矢印 にて示すように方位差が大きい領域が増加していた。な お，試験片の厚さ方向による差異は認められなかった。
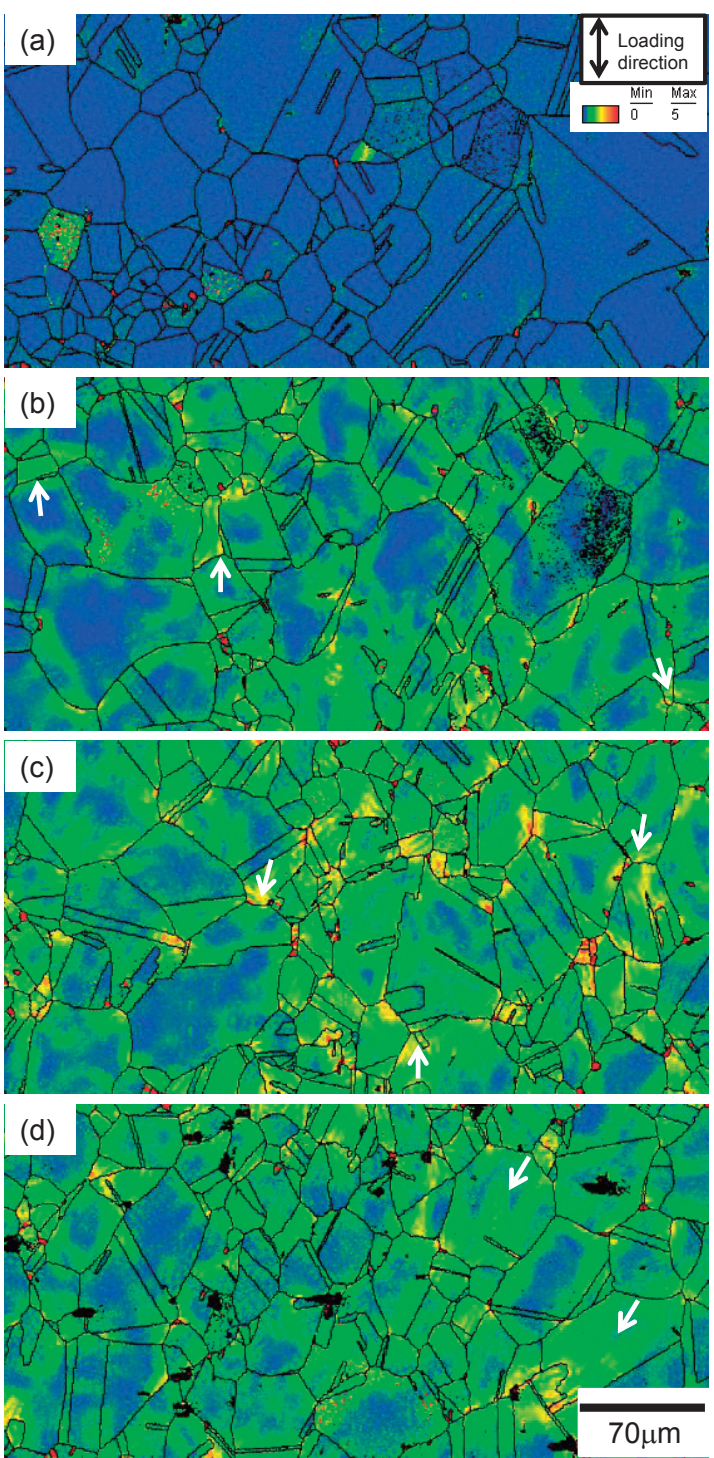

Fig.6 KAM maps of interrupted and tensile deformed specimen,

(a) before creep, (b) lifetime ration 0.47 , (c) lifetime ration 0.70 ,

(d) tensile strain of $5 \%$

次に引張変形とクリープ変形の $\mathrm{KAM}$ マップの違いに ついて比較する．5\%引張中断材(d)は 5.1\%にて中断した クリープ中断材(b)とは若干異なり, 結晶粒界のみならず 粒内においても矢印に示す領域のように方位差が大きい 領域が認められた。すなわち，5\%引張中断材はクリープ 中断材よりも結晶粒内全体にひずみが蓄積したと考えら れる，一方，クリープ中断材では，結晶粒界近傍に方位 差の大きな領域がより多いことから，クリープひずみは 主に粒界近傍に蓄積したと考えられる。よって，粒界に おけるクリープき裂の発生は，粒界近傍での高いひずみ が要因であると考えられる. $5 \%$ 引張中断材と寿命比 0.47 の中断材の KAM の分布を比較したものを Fig.7 に示す. 引張材およびクリープ材ともに, 試験片の肉厚中央で取 得した EBSD データより算出した KAM 值の分布である. 変形モードの違いによらず，方位差の分布はほぼ同じで あった.また, クリープ中断材 KAM の平均值は 0.978, $5 \%$ 
引張中断材の平均值は 1.02 とほぼ同じであった.この結 果は，負荷モードによらず導入される方位差はほぼ同じ であるが，クリープ中断材のほうがより粒界近傍に変形 が集中していることを示唆している。そこで，クリープ 中断材の結晶粒界近傍のミクロ組織を詳細に観察するた め, SEM/ECCI 法を用いて観察を実施した。

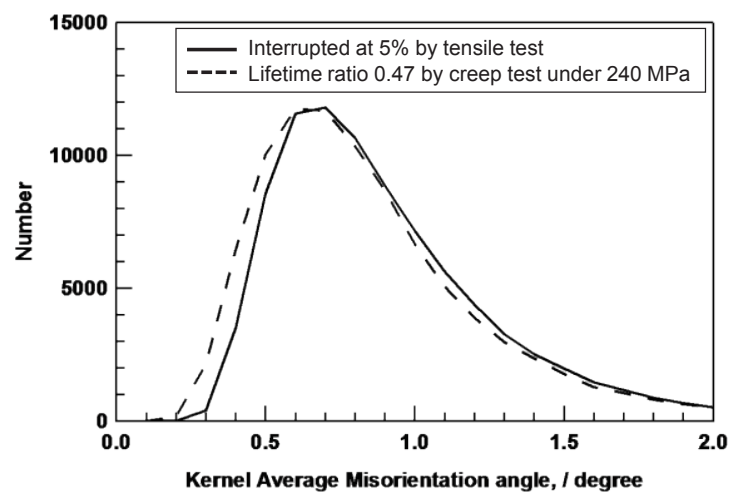

Fig.7 The difference of distributions of KAM value under creep and tensile deformation mode.

寿命比 0.70 のクリープ中断材のクラック近傍の反射電 子像を Fig.8(a)に示す. 写真中央の粒界に微細なクリープ き裂が発生しており, クラック周りおよび粒内には多く のチャネリングコントラストが発生していた。 また，き 裂が発生していない粒界では，いくつかの炭化物が観察 されるとともに，炭化物の周りにサブグレイン組織が観 察された. 次にき裂近傍を拡大した写真を Fig.8 (b)に示す. 結晶粒内の白い微細な粒子は炭窒化物もしくは $\mathrm{Cu}$ 相, 非 常に微細な黒い粒子は $\mathrm{Cr}$ 炭化物であると推察される ${ }^{1)}$. また結晶粒内には，多数の転位が観察された。一方，結 晶粒界には，約 $100 \mathrm{~nm}$ 程度の回復サブグレイン組織が形 成されていた。また一部転位セルも形成されていた。サ ブグレインの中には，転位は観察されなかった。以上よ り，結晶粒内は微細な炭化物および $\mathrm{Cu}$ 相により析出強化 されているが，粒界近傍では動的回復およびサブグレイ ンの形成が優先的に生じていた。これらの形成が結晶粒 界近傍の転位密度を低下させ, 結晶粒界近傍においてク リープ変形が優先的に生じたと考えられる。また，KAM マップで示した粒界近傍の方位差は，このサブバウンダ リーの形成によるもと考えられる。

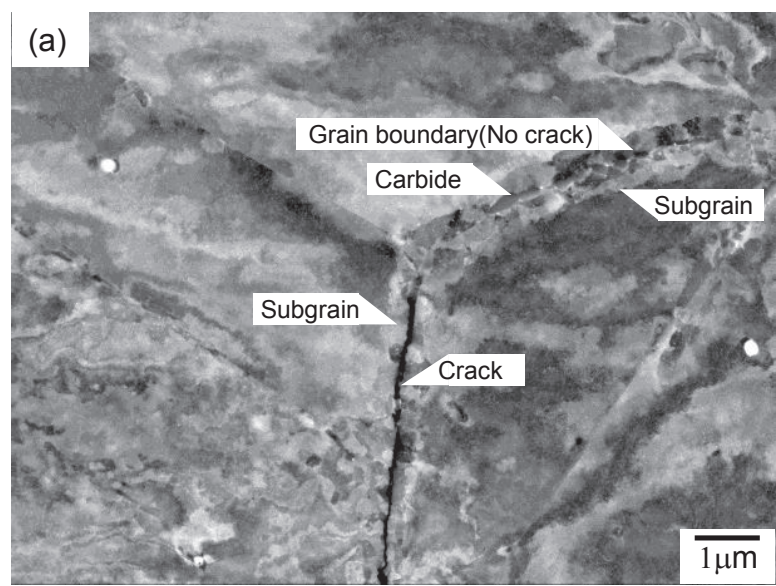

(b)

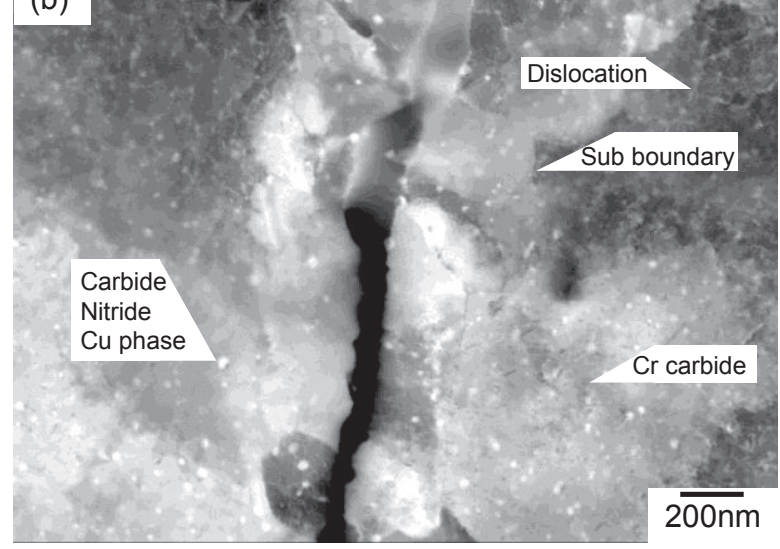

Fig.8 Back scatter electron images of lifetime ratio 0.70 specimen .

(a) the creep crack and channeling contrast, (b) precipitates and sub grains feature.

\section{$3 ・ 4$ SEM/EBSD 法によるクリープひずみ評価 \\ これまでオーステナイト系ステンレス鋼について,}

SEM/EBSD 法によるクリープひずみおよびクリープ寿命 を定量化する手法が多数報告されている ${ }^{20)-23)}$. そこで火 SUS304J1HTB についても, 同様に方位差パラメータとひ ずみの関係を検討した。 火 SUS304J1HTB について, GOSave(area)とひずみの関係を Fig.9 に示す. クリープ試 験材の結果は，破断材および加速域における中断材であ る.併せて $650^{\circ} \mathrm{C}$ における高温引張試験の結果 ${ }^{19)}$ も示す. クリープ中断材および破断材のひずみにおける GOSave(area)の変化は, 引張中断材のひずみおける GOSave(area)の変化とほぼ一致する。著者ら ${ }^{23)}$ は SUS316 について方位差パラメータとひずみの関係は, 遷移クリ 一プ域，定常クリープ域，加速クリープ域によって傾き が異なることを明らかにし，加速クリープ以降では，歪 みと方位差の関係は直線関係が成り立たないことを明ら かにしている．またこの要因として，結晶粒内の回復の 違いによるものと結論付けた。一方，火SUS304J1HTBに おいて高温引張およびクリープ中断材ともに同様の傾き を示したのは, Fig.8 (b)に示す微細な炭化物および $\mathrm{Cu}$ 相 の析出強化により粒内の回復が抑制され，粒界近傍のわ 
ずかな領域のみで回復が生じ破壊に至ったためであると 考えられる，今後，異なるクリープ条件についても，同 様の変化が生じるか明らかにする必要があるが，火 SUS304J1HTB のクリープひずみ評価手法として $\mathrm{SEM} / \mathrm{EBSD}$ 法の方位差パラメータは，期待できるパラメ ータであるといえる。

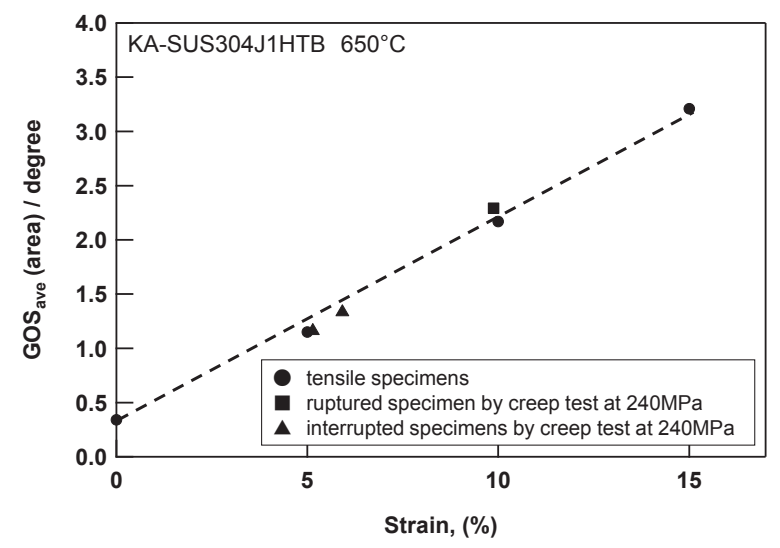

Fig.9 The relationship between interrupted strain and $\mathrm{GOS}_{\text {ave }}$ (area) under creep and tensile deformation mode.

\section{4 結 言}

オーステナイト系ステンレス鋼火 SUS304J1HTB につ いて, クリープ特性およびクリープ劣化メカニズムにつ いて検討し，以下の結論を得た。

$650^{\circ} \mathrm{C}$ におけるクリープ特性は，遷移クリープ，最小ク リープ速度および加速クリープの 3 つの領域に分けられ

る. 加速クリープは寿命の約 0.1 から 0.3 程度で生じ，寿 命の大半が加速クリープであった.

光学顕微鏡観察によるミクロおよびクリープき裂の観 察の結果，寿命の 0.47 からクリープき裂が発生し，増加 していていくことを明らかにした.

EBSD 法および ECCI 法による結果より,このクリープ き裂は，粒内では析出強化により変形が抑制されるが, 粒界近傍において優先的に動的回復およびサブグレイン が形成されるため生じるためと推察した.

GOSave(area)とひずみの関係は, 加速クリープ域におい ても, 引張試験結果と同様に良い相関関係をもつことを 明らかにした。

\section{参 考 文 献}

1) H. Semba, Y. Sawaragi, K. Ogawa, A. Natori and T. Kan, "Development of "SUPER304H" austenitic stainless steel tubes with high temperature strength for USC boilers", Materia Japan, Vol.41, No.2, pp.120-122 (2002).

2) M. Sukegawa, M. Shiga, C. Asano, Y. Tobita and S. Kirihara, "Fundamental study on non-destructive detection of creep damage for 18Cr-Ni(SUS 304) steel", Journal of Materials Science, Japan, Vol.34, No.387, pp.1478-1482 (1985).
3) L. B. Niu, A. Katsuta, M. Kobayashi and H. Takaku, "Initiation and growth behavior of creep voids in an austenitic steel with high ductility under multi-axial stresses", ISIJ International, Vol.43, No.2, pp. 251-255 (2003).

4) NRIM/Metallographic Atlas/No.M-1/1999.

5) H. Tanaka, M. Murata, F. Abe and K. Yagi, "Effects of grain boundary precipitates on long-term creep rupture properties of SUS347H steel", Tetu-to-Hagane, Vol.83, No.1, pp.72-77 (1997).

6) H. Tanaka, M. Murata, F. Abe and K. Yagi and T. Sugita, "Evaluation of creep-damaged microstructure in austenitic stainless steels by surface observations", Tetu-to-Hagane, Vol.84, No.4, pp.61-66 (1998).

7) C. Y. Chi, H. Y. Yu, J. X. Dong, W. Q. Liu, S. C. Cheng, Z. D. Liu and X. S. Xie, "The precipitation strengthening behavior of $\mathrm{Cu}$-rich phase in $\mathrm{Nb}$ contained advanced $\mathrm{Fe}-\mathrm{Cr}-\mathrm{Ni}$ type austenitic heat resistant steel for USC power plant application" , Chinese Materials Reseach Society, Vol.22, No.3, pp.175-185 (2012).

8) S. P. Tan, Z. H. Wang, S. C. Cheng, Z. D. Liu, J. C. Han and W. T. Fu, "Effect of $\mathrm{Cu}$ content on aging precipitation behaviors of $\mathrm{Cu}$-rich phase in $\mathrm{Fe}^{-} \mathrm{Cr}-\mathrm{Ni}$ alloy", Journal of Iron and Steel Research International, Vo.17, No.5, pp.63-68 (2010).

9) D. B. Park, S. M. Hong, K. H. Lee, M. Y. Huh, J. Y. Suh, S. C. Lee and W. S. Jung, "High-temperature creep behavior and microstructural evolution of an $18 \mathrm{Cr}-9 \mathrm{Ni}-3 \mathrm{Cu}-\mathrm{Nb}-\mathrm{VN}$ austenitic stainless steel", Materials Characterization, Vol.93, pp.52-61 (2014).

10) K. Kubushiro, K. Nomura, S. Takahashi and T. Tanoue, "Effect of initial plastic strain on stress relaxation behavior in austenitic steels", Proceedings of the 12th Inter. Conference on Creep and Fracture of Engineering Materials and structures (2012).

11) P. Viklund, A. Hjornhede, P. Henderson, A. Stalenheim and R. Pettersson, "Corrosion of superheater materials in a waste-to-energy plant", Fuel Processing Technology, Vol.105, pp.106-112 (2013).

12) I. T. Hong and C. H. Koo, "Antibacterial properties, corrosion resistance and mechanical properties of Cu-modified SUS 304 stainless steel", Material Science and Engineering A, Vol.393, pp.213-222 (2005).

13) R. Viswanathan, J. Sarver and J. M. Tanzosh, "Boiler materials for ultra-supercritical coal power plantssteamside oxidation”, ASM International, Vol.15, No.2, pp.255-274 (2006).

14) B. Prabha, P. Sundaramoorthy, S. Suresh, S. Manimozhi and B. Ravishankar, "Studies on stress corrosion cracking of super $304 \mathrm{H}$ austenitic stainless steel" Journal of Materials Engineering and Performance, Vol.18, pp1294-1299 (2009).

15) "Standard for misorientation analysis by electron backscatter diffraction (EBSD) for material characterization" The Society of Materials Science, Japan, (2016)

16) N. Shinya, J. Kyono, H. Tanaka, M. Murata and S. Yokoi, "Creep rupture properties and creep fracture 
mechanism maps for type 304 stainless steel" Tetu-to-Hagane, Vol.69, No.4, pp.1668-1675 (1983).

17) N. Shinya, H. Tanaka, M. Murata, M. Kaise and S. Yokoi, "Creep fracture mechanism maps based on creep rupture tests up to about $100000 \mathrm{~h}$ for type 316 stainless steel", Tetu-to-Hagane, Vol.71, No.1, pp.114-120 (1983).

18) H. Tanaka, N. Shinya and M. Murata, "Creep fracture modes at high temperature in SUS321H", Tetu-to-Hagane, Vol.78, No.1, pp.90-96 (1992).

19) K. Nomura, K. Kubushiro, Y. Sakakibara, S. Takahashi and H. Yoshizawa, "Effect of grain size on plastic strain analysis by EBSD for austenitic stainless steels with tensile strain at $650^{\circ} \mathrm{C}$ ", Journal of the Society of Materials Science Japan, Vol.61, pp.371-376 (2012).

20) C. Fukuoka, K. Morishima, H. Yoshizawa and K. Mino, "Misorientation development in grains of tensile strained and crept $2.25 \% \mathrm{Cr}-1 \% \mathrm{Mo}$ steel", Scripta Materialia, Vol.46, pp.61-66 (2002).

21) R. Yoda, T. Yokomaku and N. Tsuji, "Plastic deformation and creep damage evaluations of type 316 austenitic stainless steels by EBSD", Materials Characterization, Vol.61, pp.913-932 (2010).

22) K. Fujiyama, Y. Mizuguchi, Y. Taniguchi and H. Kimachi, "EBSD analysis of creep damage process in SUS304HTB steel", Journal of Materials Science, Japan, Vol.62, No.5, pp.305-310 (2013)

23) K. Kubushiro, Y. Sakakibara and T. Ohtani, "Creep strain analysis of austenitic stainless steel by SEM/EBSD”, Journal of the Society of Materials Science, Japan, Vol.64, No.2, pp.106-112 (2015). 